\title{
Rodents as potential reservoirs for Borrelia spp. in northern Chile
}

\author{
Roedores como potenciais reservatórios de Borrelia spp. no norte do Chile \\ Richard Said Thomas Sánchez'; Adriana Milena Santodomingo Santodomingo'; Sebastián Muñoz-Leal²; \\ María Carolina Silva-de la Fuente ${ }^{1,3}$; Sebastián Llanos-Soto4; Lucila Moreno Salas ${ }^{5}$; Daniel González-Acuña1* (1)

\begin{abstract}
'Laboratorio de Parásitos y Enfermedades de Fauna Silvestre, Departamento de Ciencia Animal, Facultad de Ciencias Veterinarias, Universidad de Concepción, Chillán, Ñuble, Chile

${ }^{2}$ Departamento de Medicina Veterinária Preventiva e Saúde Animal, Faculdade de Medicina Veterinária e Zootecnia, Universidade de São Paulo - USP, São Paulo, SP, Brasil

${ }^{3}$ Instituto de Medicina Preventiva Veterinaria, Facultad de Ciencias Veterinarias, Universidad Austral de Chile, Valdivia, Chile ${ }^{4}$ Departament of Population Medicine and Diagnostic Sciences, College of Veterinary Medicine, Cornell University, Ithaca, New York, NY, USA
\end{abstract} \\ ${ }^{5}$ Departamento de Zoología, Facultad de Ciencias Naturales y Oceanográficas, Universidad de Concepción, Concepción, Bío-Bío, Chile
}

How to cite: Thomas R, Santodomingo AM, Muñoz-Leal S, Silva-de la Fuente MC, Llanos-Soto S, Moreno-Salas L, et al. Rodents as potential reservoirs for Borrelia spp. in northern Chile. Braz J Vet Parasitol 2020; 29(2): e000120. https://doi.org/10.1590/ S1984-29612020029

\begin{abstract}
Small mammals play an essential role in the transmission and maintenance cycles of Borrelia spirochetes. In Chile, recent studies have characterized novel Borrelia genotypes in ticks collected from small mammals, a fact that suggests these vertebrates are hosts for spirochetes from this genus. Considering this evidence, the goal of this study was to determine the presence of Borrelia DNA in small mammals inhabiting northern Chile. In winter of 2018, 58 small mammals were captured in five localities. Blood samples were collected from rodents and DNA was extracted to determine the presence of Borrelia DNA by PCR targeting the flaB gene and rrs-rrlA intergenic spacer (IGS). From three individuals (5\%), belonging to two rodent species of Cricetidae family (Phyllotis xanthopygus and Oligoryzomys longicaudatus), we retrieved three flaB and two IGS Borrelia genotypes. Phylogenetic analyses performed with both Maximum Likelihood and Bayesian inferences showed that our sequences grouped with homologous genotypes from the relapsing fever and Lyme borreliosis groups. Our findings suggest that $P$. xanthopygus and O. Iongicaudatus rodents may play a role as reservoirs for borrelial spirochetes in Chile.
\end{abstract}

Keywords: Borrelia, infectious diseases, small mammals, reservoirs, rodent, Chile.

\begin{abstract}
Resumo
Pequenos mamíferos possuem um papel essencial na transmissão e manutenção de espiroquetas do gênero Borrelia. No Chile, estudos recentes têm descrito novos genótipos de Borrelia em carrapatos, parasitando pequenos mamíferos. Isso sugere que esses vertebrados podem atuar como possíveis reservatórios dessas espiroquetas. Considerando-se essa evidência, o objetivo deste estudo foi determinar a presença de DNA de Borrelia em pequenos mamíferos da região norte do Chile. Durante o inverno de 2018, 58 pequenos mamíferos foram capturados em cinco localidades. Amostras de sangue obtidas a partir dos indivíduos capturados foram submetidas à extração de DNA e ensaios de PCR, para a detecção de Borrelia spp. baseados no gene flaB e espaçador intergênico rrs-rrlA (IGS). A partir de três espécimes (5\%) pertencentes a duas espécies de roedores da família Cricetidae (Phyllotis xanthopygus e Oligoryzomys longicaudatus) obtiveram-se três genótipos de Borrelia para o gene flaB e dois para IGS. Análises filogenéticas inferidas, usando-se os métodos Bayesiano e de Máxima Verossimilhança, indicaram que as sequências geradas neste estudo agrupam-se com borrelias do grupo da Febre Recorrente e Borreliose de Lyme. Os achados deste estudo sugerem que roedores $P$. xanthopygus e $O$. longicaudatus poderiam atuar como possíveis reservatórios para Borrelia spp. no Chile.
\end{abstract}

Palavras-chave: Borrelia, doenças infecciosas, pequenos mamíferos, reservatórios, roedor, Chile.

Received January 4, 2020. Accepted April 15, 2020.

*Corresponding author: danigonz@udec.cl

This is an Open Access article distributed under the terms of the Creative Commons Attribution License, which permits unrestricted use distribution, and reproduction in any medium, provided the original work is properly cited. 


\section{Introduction}

In Chile, studies on bacterial infections in small mammals have been performed mostly in the central and southern regions of the country (Müller et al., 2018; Llanos-Soto \& González-Acuña, 2019). In the northern region of Chile, research regarding bacterial infection on mammals consists in three surveys focusing on Escherichia and Salmonella of marine vertebrates (Otaria flavescens) (Salinas et al., 2010; Sturm et al., 2011; Toro et al., 2015). Data on vector-borne bacterial pathogens transmitted by mites or ticks are absent for this region of the country.

Rodentia is among the most diverse mammal order in Chile, with 69 species distributed along the country (MMA, 2018). This group of vertebrates plays an important role in the maintenance and propagation of tick-borne pathogens (bacterial, protozoan and viral) in urban and natural environments (Llanos-Soto \& González-Acuña, 2019). Globally, rodents act as hosts for tick populations and serve as reservoirs for zoonotic pathogenic agents, such as Borrelia species (Cutler, 2015; Cutler et al., 2017).

Spirochetes in the genus Borrelia merge their transmission cycles with vertebrates and their associated ticks in wild ecosystems (Kurtenbach et al., 1995; Talagrand-Reboul et al., 2018). For instance, in the Northern Hemisphere, human-pathogenic Borrelia burgdorferi sensu lato (s.l.) spirochetes use rodents and hard ticks (Acari: Ixodidae) of the Ixodes ricinus species complex as reservoirs and vectors, respectively, and are the causative agents of Lyme borreliosis (LB) in humans (Donahue et al., 1987; Kurtenbach et al., 1995; Hazler \& Ostfeld, 1995; Rauter \& Hartung, 2005). Moreover, small mammals and some species of soft ticks (Acari: Argasidae) of the Ornithodoros genus maintain natural foci of relapsing fever (RF) borreliae in tropical and subtropical ecosystems in both hemispheres (Talagrand-Reboul et al., 2018).

Despite their importance for the maintenance of Borrelia infections elsewhere, the role of rodents as sylvatic reservoirs for this genus of spirochetes has not been properly addressed in Chile, since most studies have focused on vectors rather than potential vertebrate reservoirs. For instance, only one valid genospecies, Borrelia chilensis, has been identified in Ixodes stilesi ticks collected from the environment, and from long-tailed pygmy rice rats (Oligoryzomys longicaudatus) (Ivanova et al., 2014). In this case, although ticks were infected with B. chilensis, this does not necessarily mean that $O$. longicaudatus were carrying the spirochetes, since positive nymphs could have acquired the bacterium through a previous blood meal (Guttman et al., 1996). A similar scenario encompasses the recent findings of novel Borrelia genotypes in Ixodes sigelos s.l. group, and an Ornithodoros sp. closely related with Ornithodoros atacamensis in northern Chile (Muñoz-Leal et al., 2019a, b), for which their associated hosts, i. e. rodents of genus Phyllotis, were not assessed for Borrelia infection (Muñoz-Leal et al., 2019a). In this context, to elucidate the identity of vertebrate reservoirs for Borrelia is still a crucial step to understand transmission cycles of these bacteria in Chilean ecosystems. In this study, we aimed to assess the role of rodents and marsupials from northern Chile as potential reservoirs for Borrelia spp. through molecular analyses performed in blood obtained from these mammals.

\section{Material and Methods}

\section{Study area}

This study surveyed rodents in five localities belonging to hyper-arid hydrographic regions from northern Chile (Figure 1) during July (Austral winter) of 2018. Hyper-arid hydrographic region in Chile is characterized by having an annual precipitation and potential evapotranspiration ratio $<0.05$; the annual precipitation does not exceeds $100 \mathrm{~mm}$, presenting an annual water deficit higher than $1200 \mathrm{~mm}$; and dryness prevails throughout the year with a short peak of humidity that lasts one month (MMA, 2018).

\section{Sample collection}

Rodents and marsupials were captured using Sherman-like traps. Eighty traps remained active during two consecutive nights (10 hours per night) in each locality, and were placed along four parallel lines distanced approximately $100 \mathrm{~m}$ from each other, with 20 traps per line (spaced $10 \mathrm{~m}$ between each other). Animal handling was performed according to protocols used in field and laboratory studies on rodents (Herbreteau et al., 2011). Fifty microliters of blood were collected from each captured rodent through puncture of the caudal ventral vein and stored in sterile tubes with $96 \%$ ethanol (Sigma-Aldrich ${ }^{\circledR}$ ). All rodents were identified to the species level using a taxonomic guide (Iriarte, 2008), and after blood collection, were released in the same place of capture. 


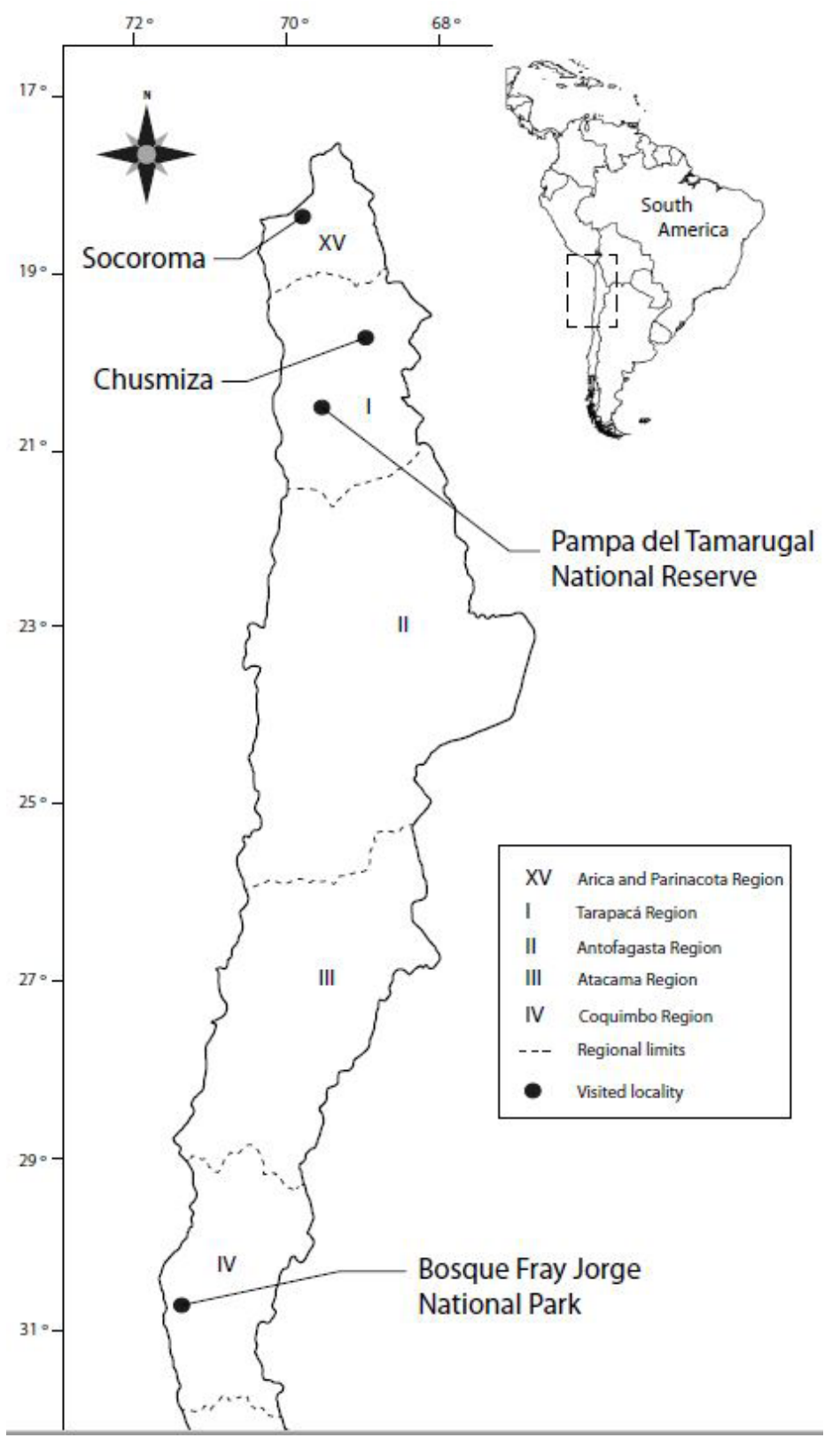

Figure 1. Map of northern Chile with the locations (black dots) were small mammals were captured.

Authorization for small mammal captures was granted by the Servicio Agrícola y Ganadero (SAG; Resolution $N^{\circ} 1532 / 2019$ and 9071/2018). Field work in national parks and reserves was authorized by the Corporación Nacional Forestal (CONAF; Permits 39/2018; 67/2019; 05/2018; 76/2018; 66/2018). All procedures were approved and carried out according to the Bioethics Committee of the School of Veterinary Sciences, Universidad de Concepción (Form CBE-19-2017).

\section{DNA extraction and gene amplification}

DNA was extracted from blood using the DNeasy Blood \& Tissue Kit (QUIAGEN, GERMANY). Forty microliters of Buffer AE (10 mM Tris-Cl; $0.5 \mathrm{mM}$ EDTA, pH 9.0) were used to suspend the final DNA yield. To test successful extractions, and rule out the presence of PCR inhibitors, DNA quantity (concentration) and quality (purity and integrity) of DNA was assessed by $A_{260} / A_{280}$ absorbance $(A)$ in each sample using an Epoch ${ }^{\mathrm{TM}}$ Microplate Spectrophotometer. Samples with an $A_{260} / A_{280}$ DNA ratio ranging between 1.6-2.0 were considered pure, and suitable for PCR amplification (Khare et al., 2014). Additionally, samples were tested through conventional PCR targeting endogenous gapdh (glyceraldehyde-3phosphate dehydrogenase) gene as an internal control following Birkenheuer et al. (2003). 
Successfully extracted samples were screened for Borrelia flagellin gene (flaB), and rrs-rrlA intergenic spacer (IGS) through nested PCR protocols, using primers listed in Table 1. Reactions were performed into a final volume of $25 \mu \mathrm{L}$ containing $12.5 \mu \mathrm{L}$ of Dream Taq Green PCR Master Mix (Thermo Scientific, USA), $1 \mu \mathrm{L}$ of each primer (10 pmol), $2 \mu \mathrm{L}$ of DNA for conventional PCR, $1 \mu \mathrm{L}$ of the product for nested rounds, and ultra-pure water to complete the final volume of the mix. Amplicons were verified in 1.5\% agarose gels stained with SYBR Safe (Life Technologies/Thermo Fisher Scientific, Carlsbad, CA), and visualized through UV light. Positive samples were purified and sequenced in both directions at AUSTRAL-omics (Valdivia, Chile).

Table 1. List of primers used for the detection and characterization of Borrelia DNA in this study.

\begin{tabular}{|c|c|c|c|c|}
\hline Target & Primer & Sequence & $\begin{array}{l}\text { Expected } \\
\text { length (bp) }\end{array}$ & Reference \\
\hline \multirow{4}{*}{$\begin{array}{l}\text { Flagelin gene } \\
\text { fragments }(f l a B)\end{array}$} & FlaLL & 5' -ACATATTCAGATGCAGACAGAGGT-3' & 658 & (Stromdahl et al., 2003) \\
\hline & FlaRL & 5' -GCAATCATAGCCATTGCAGATTGT-3' & & \\
\hline & FlaLS & 5' -AACAGCTGAAGAGCTTGGAATG-3' & 354 & \\
\hline & FlaRS & $5^{\prime}$-CTTTGATCACTTATCATTCTAATAGC-3' & & \\
\hline \multirow{4}{*}{$\begin{array}{l}\text { rrs-rrlA intergenic } \\
\text { spacer (IGS) }\end{array}$} & IGS-F & 5' -GTATGTTTAGTGAGGGGGGTG-3' & 987 & (Bunikis et al., 2004) \\
\hline & IGS-R & 5' -GGATCATAGCTCAGGTGGTTAG-3' & & \\
\hline & IGS-Fn & $5^{\prime}$-AGGGGGGTGAAGTCGTAACAAG-3' & 945 & \\
\hline & IGS-Rn & 5' -GTCTGATAAACCTGAGGTCGGA-3' & & \\
\hline
\end{tabular}

\section{Phylogenetic analyses}

The obtained sequences were edited with ProSeq Version (V) 3 (Filatov, 2009), compared using BLASTn (https://blast.ncbi.nlm.nih.gov), and aligned with records from the NCBI database using the ClustalW algorithm (Thompson et al., 1994) implemented in MEGA 7.0 (Kumar et al., 2016). Alignments for flaB gene and IGS were used to construct both Bayesian Inference (BI) and Maximun Likelihood (ML) trees with MrBayes 3.2.2. (Ronquist et al., 2012), and IQ-TREE v1.6.12 (Nguyen et al., 2015), respectively. We chose these methods because they are based on models of molecular evolution (Huelsenbeck et al., 2001; Felsenstein, 2004). Evolutionary models for BI were selected using MrBayes 3.2.2, employing the option "Iset nst=mixed rates=gamma", and the Bayesian Information Criterion (BIC) (Schwarz, 1978). ModelFinder (Kalyaanamoorthy et al., 2017) with the option "-m MFP+MERGE", and the BIC were employed to select best evolutionary models for the ML analysis (Schwarz, 1978).

$\mathrm{BI}$ was performed with two independent tests of $10^{7}$ generations, running four MCMC chains, sampling trees every 1000 generations, and discarding the first $25 \%$ as burn-in. MCMC chain correlation was confirmed with Tracer v1.7.1 (Rambaut et al., 2018). Statistical support of internal nodes was evaluated employing Bayesian posterior probabilities (BPPs) and considering values $\geq 0.70$ as strong support (Huelsenbeck \& Ronquist, 2001). The ML analysis was carried using rapid hill-climbing and stochastic disturbance methods, evaluating the robustness of the inferred tree with 1000 pseudo-replicates of ultrafast bootstrapping. We used the criteria of Minh et al. (2013) to evaluate the ultrafast bootstrap: values $<70 \%$ were considered non-significant statistical support; values between $70-94 \%$ as moderately significant; and values $\geq 95 \%$ as highly significant.

\section{Results}

\section{Positive animals and PCR}

A total of 58 small mammals belonging to 12 species in the families Cricetidae, Muridae and Didelphidae were captured (Table 2). Although DNA purity obtained after measurements of $A_{260} / A_{280}$ absorbance ratio was optimal in 56/58 of the samples (97\%), five samples (including the two with low $A_{260} / A_{280}$ absorbance ratio) were negative after GAPDH gene PCR and excluded from further analyses. Three out of 53 rodents (5\%) were positive for Borrelia flaB screening, and two of these samples were positive for IGS (4\%) (Table 2). 
Table 2. Number and identity of small mammals captured in Northern Chile. Specimens positive for Borrelia by PCR assays are highlighted in bold. Abbreviations: BFJNP, Bosque Fray Jorge National Park; Ch, Chusmiza; Par, Parinacota; PTNR, Pampa del Tamarugal National Reserve; Soc, Socoroma.

\begin{tabular}{|c|c|c|c|c|c|}
\hline Order & Family & Species & Locality & Geographic coordinates & $\begin{array}{c}\text { No. Positive/ } \\
\text { No. Capture }\end{array}$ \\
\hline Didelphimorphia & Didelphidae & Thylamys elegans & BFJNP & $30^{\circ} 39^{\prime} 07.07^{\prime \prime} \mathrm{S}, 71^{\circ} 41^{\prime} 09.44^{\prime \prime} \mathrm{W}$ & $0 / 2$ \\
\hline Didelphimorphia & Didelphidae & Thylamys pallidor & Soc & $18^{\circ} 16^{\prime} 44.30^{\prime \prime} \mathrm{S}, 69^{\circ} 35^{\prime} 28.40^{\prime \prime} \mathrm{W}$ & $0 / 1$ \\
\hline Rodentia & Cricetidae & Abrothrix andinus & Soc & $18^{\circ} 12^{\prime} 00.00^{\prime \prime S}, 69^{\circ} 16^{\prime} 00.12^{\prime \prime} \mathrm{W}$ & $0 / 1$ \\
\hline Rodentia & Cricetidae & Abrothrix andinus & Par & $18^{\circ} 12^{\prime} 00.00^{\prime \prime} \mathrm{S}, 69^{\circ} 16^{\prime} 00.12^{\prime \prime} \mathrm{W}$ & $0 / 4$ \\
\hline Rodentia & Cricetidae & Abrothrix berlepschii & Par & $18^{\circ} 12^{\prime} 00.00^{\prime \prime} \mathrm{S}, 69^{\circ} 16^{\prime} 00.12^{\prime \prime} \mathrm{W}$ & $0 / 1$ \\
\hline Rodentia & Cricetidae & Abrothrix berlepschii & Soc & $18^{\circ} 16^{\prime} 44.30^{\prime \prime} \mathrm{S}, 69^{\circ} 35^{\prime} 28.40^{\prime \prime} \mathrm{W}$ & $0 / 4$ \\
\hline Rodentia & Cricetidae & Abrothrix jelskii & Par & $18^{\circ} 12^{\prime} 00.00^{\prime \prime} \mathrm{S}, 69^{\circ} 16^{\prime} 00.12^{\prime \prime} \mathrm{W}$ & $0 / 1$ \\
\hline Rodentia & Cricetidae & Abrothrix longipilis & BFJNP & $30^{\circ} 39^{\prime} 07.07^{\prime \prime} \mathrm{S}, 71^{\circ} 41^{\prime} 09.44^{\prime \prime} \mathrm{W}$ & $0 / 1$ \\
\hline Rodentia & Cricetidae & Abrothrix olivacea & BFJNP & $30^{\circ} 39^{\prime} 07.07^{\prime \prime S}, 71^{\circ} 41^{\prime} 09.44^{\prime \prime} \mathrm{W}$ & $0 / 3$ \\
\hline Rodentia & Cricetidae & Oligoryzomys longicaudatus & BFJNP & 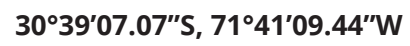 & $1 / 1$ \\
\hline Rodentia & Cricetidae & Phyllotis limatus & Soc & $18^{\circ} 16^{\prime} 44.30^{\prime \prime} \mathrm{S}, 69^{\circ} 35^{\prime} 28.40^{\prime \prime} \mathrm{W}$ & $0 / 1$ \\
\hline Rodentia & Cricetidae & Phyllotis magister & Soc & $18^{\circ} 16^{\prime} 44.30^{\prime \prime} \mathrm{S}, 69^{\circ} 35^{\prime} 28.40^{\prime \prime} \mathrm{W}$ & $0 / 1$ \\
\hline Rodentia & Cricetidae & Phyllotis xanthopygus & $\mathrm{Ch}$ & $19^{\circ} 41^{\prime} 01.27^{\prime \prime S}, 69^{\circ} 11^{\prime} 53.05^{\prime \prime} \mathrm{W}$ & $0 / 4$ \\
\hline Rodentia & Cricetidae & Phyllotis xanthopygus & PTNR & $20^{\circ} 28^{\prime} 14.03^{\prime \prime} \mathrm{S}, 69^{\circ} 40^{\prime} 25.16^{\prime \prime} \mathrm{W}$ & $0 / 4$ \\
\hline Rodentia & Cricetidae & Phyllotis xanthopygus & Par & $18^{\circ} 12^{\prime} 00.00^{\prime \prime} \mathrm{S}, 69^{\circ} 16^{\prime} 00.12^{\prime \prime} \mathrm{W}$ & $0 / 5$ \\
\hline Rodentia & Cricetidae & Phyllotis xanthopygus & Soc & $18^{\circ} 16^{\prime} 44.30^{\prime \prime S}, 6^{\circ} 35^{\prime} 28.40^{\prime \prime} \mathrm{W}$ & $2 / 16$ \\
\hline Rodentia & Muridae & Mus musculus & Soc & $18^{\circ} 16^{\prime} 44.30^{\prime \prime} \mathrm{S}, 69^{\circ} 35^{\prime} 28.40^{\prime \prime} \mathrm{W}$ & $0 / 2$ \\
\hline Rodentia & Muridae & Rattus rattus & PTNR & $20^{\circ} 28^{\prime} 14.03^{\prime \prime} \mathrm{S}, 69^{\circ} 40^{\prime} 25.16^{\prime \prime} \mathrm{W}$ & $0 / 1$ \\
\hline Total & & & & & $3 / 53$ \\
\hline
\end{tabular}

Three different genotypes were obtained for flaB gene. Two flaB sequences of 304 bp $(99.67 \%$ of identity between them) were retrieved from blood of two Phyllotis xanthopygus collected in Socoroma (named as Borrelia sp. A10 and Borrelia sp. A44). BLASTn comparisons revealed that flaB sequences for Borrelia sp. A10 and Borrelia sp. A44 were $97.48 \%$ (271/278 bp, 91\% query cover, 0 gap, 5e-130 E-value) and 97.12\% (270/278 bp, 91\% query cover, 0 gap, 2e-128 E-value) identical with Borrelia sp. 95325 (HM583797) characterized from undetermined Ornithodoros sp. from Bolivia (Parola et al., 2011), respectively. On the other hand, a different genotype of flaB gene (307 bp) was obtained from one O. longicaudatus captured in Bosque Fray Jorge National Park. After BLASTn comparisons, this sequence (named as Borrelia sp. A53) was $98.70 \%$ (303/307 bp, 94\% query cover, 0 gap, 3e-151 E-value) identical to Borrelia spp. characterized from ticks belonging to I. sigelos group in Chile (MH187987 and MH178397; Muñoz-Leal et al., 2019a). The sequences of flaB from Borrelia sp. A10, A44, and A53 were deposited in GenBank under accession numbers MN596012, MN596013, and MN596014, respectively.

Two different IGS sequences were obtained from the same samples of $P$. xantophygus positive for flaB gene. Sequences were $96.49 \%$ identical between them and 94.36\% identical (202/214 bp, 41\% query cover, 3 gaps, 8 e-85 E-value) to Borrelia sp. TM (DQ000283; referred as "cf. Borrelia crocidurae" amplified from ticks). IGS sequences from Borrelia sp. A10 and A44 were deposited in Genbank under accession numbers MN598782 and MN598783, respectively.

\section{Phylogenetic analyses}

Overall, BI and ML phylogenetic trees for flaB and IGS depicted similar and well-supported logic topologies, grouping Borrelia spp. into LB and RF groups. In particular, phylogenetic analyses for flaB gene positioned our sequences within a clade with Borrelia sp. 95325 (HM583797) having statistically significant support (BPP=1 
in Figure 2A, and Bootstrap=100 in Figure 2B). For the BI analysis, the clade composed by our sequences and Borrelia sp. 95325 formed a clade with high statistical support (BPP=0.98 in Figure 2A) with Borrelia latyschewii (JF708952), Borrelia microti (JF708951), Borrelia duttonii (NC011229), Borrelia recurrentis (CP000993), Borrelia crocidurae (CP004267), Borrelia hispanica (MF432465), and Borrelia persica (NZAYOT01000225). However, the internal relations of this clade were undefined. On the other hand, with high support (Bootstrap=97 in Figure 2B), the ML analysis supported Borrelia sp. A10 and A44 as independent branches into a monophyletic group with Borrelia sp. 953225 (HM583797). On the other hand, and with high statistical support (BPP= 0.84 in Figure 2A, and Bootstrap= 90 in Figure 2B), Borrelia sp. A53 clustered with Borrelia genotypes characterized from ticks belonging to the I. sigelos group (MH187987, MH178397), with B. chilensis VA1 (CP009910), and Borrelia sp. ISIG1 (KX417768) obtained from I. cf. neuquenensis, and I. sigelos from Argentina as sister groups (Figure 2).

With high statistical support (BBP= 1 in Figure $3 A$, and Bootstrap= 96 in Figure 3B), phylogenetic analyses for IGS sequences showed that Borrelia sp. A10 and Borrelia sp. A44 form an independent clade related to Borrelia spp. belonging to the relapsing fever group (Figure 3).
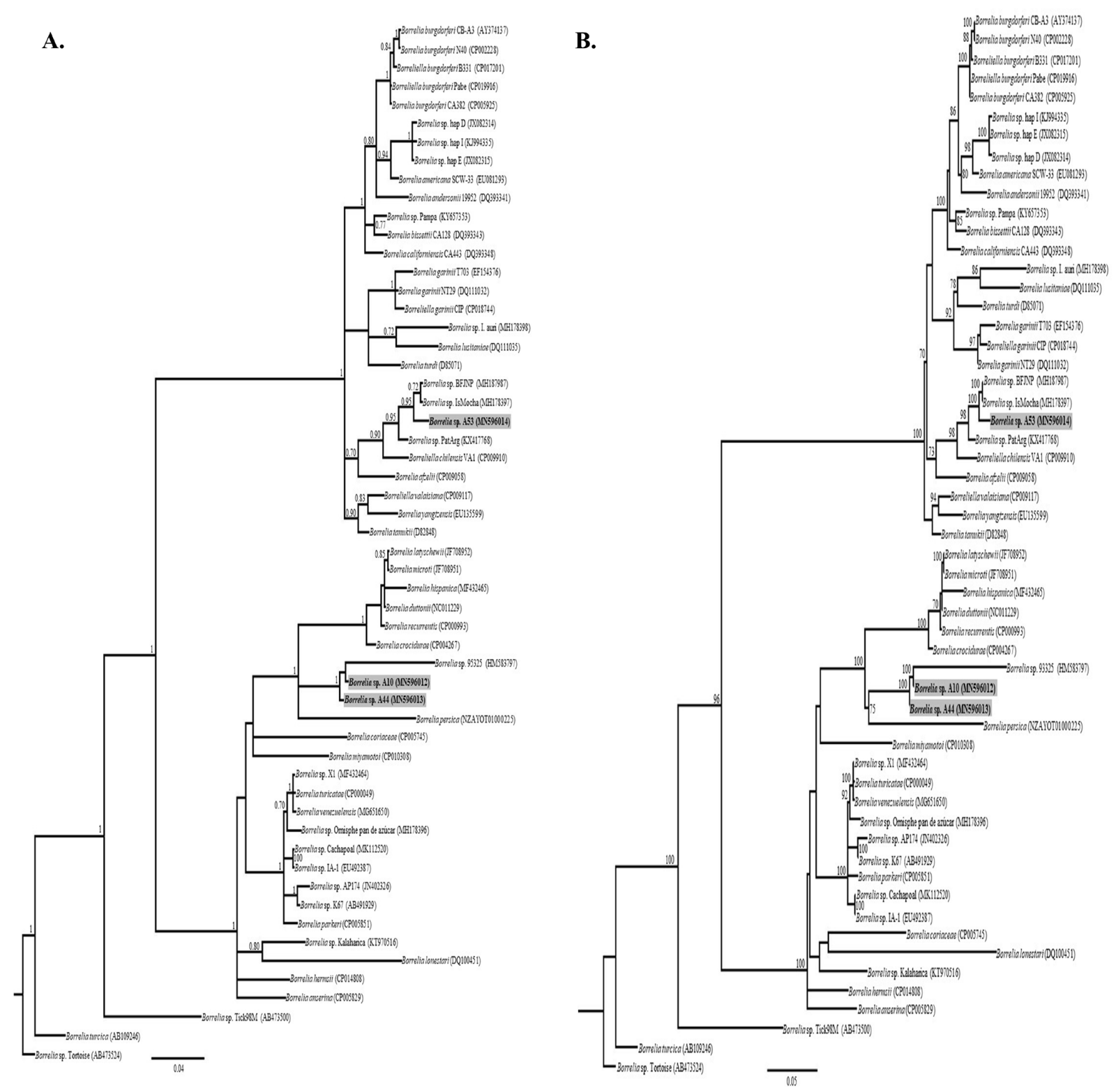

Figure 2. Bayesian (A) and Maximum Likelihood (B) phylogenetic trees for Borrelia flaB gene (alignment length, 657 bp). Otherwise omitted, numbers above branches represent BPP and bootstrap values $\geq 0.70$ and $\geq 70 \%$, respectively. GenBank accession numbers for the sequences included in the analyses are embedded in each tree. The position of Borrelia sp. A10, A44, and A53 are highlighted in bold with a gray background. 
A.

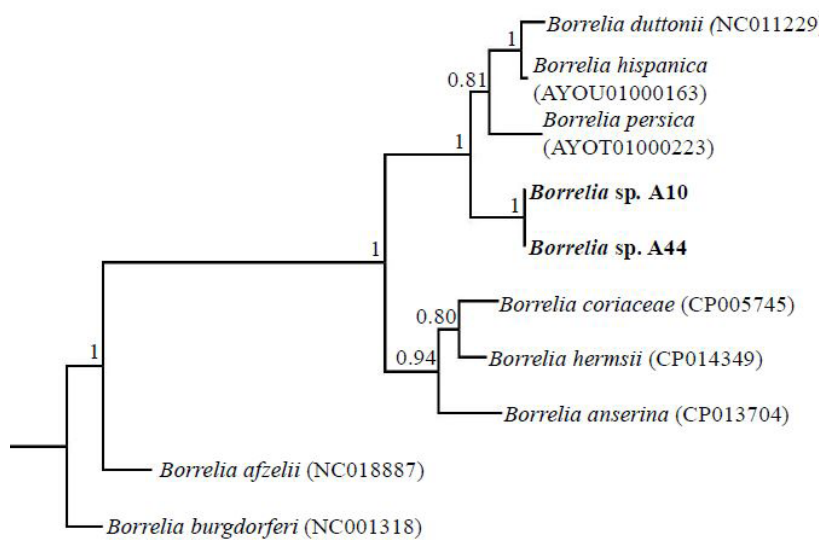

B.

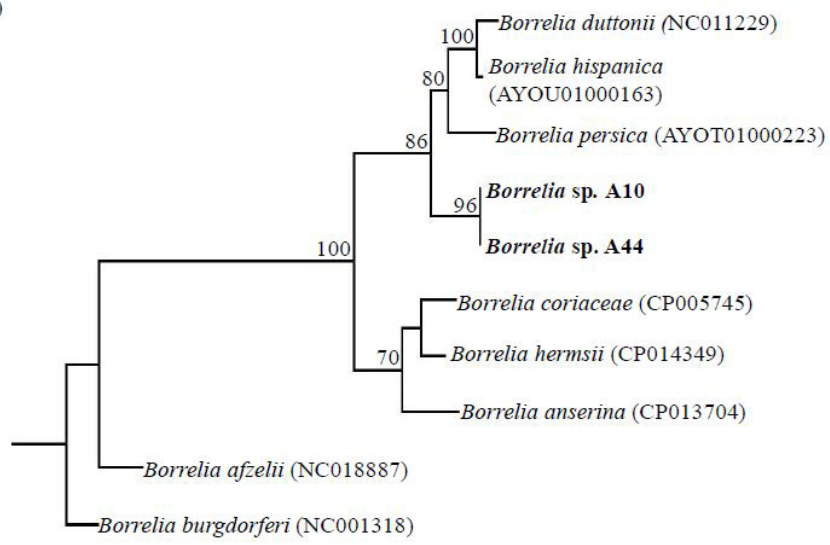

Figure 3. Bayesian (A) and Maximum Likelihood (B) phylogenetic trees for Borrelia IGS sequences gene (alignment length, 713 bp). Otherwise omitted, numbers above branches represent BPP and bootstrap values $\geq 0.70$ and $\geq 70 \%$, respectively. GenBank accession numbers for the sequences included in the analyses are embedded in each tree. The position of Borrelia sp. A10, and A44 are highlighted in bold with a gray background.

\section{Discussion}

The identification of wild vertebrate reservoirs implicated in the maintenance of pathogenic agents should be considered a permanent task in scientific research (Karesh et al., 2012). Rodents are important sylvatic reservoirs, as at least 217 out of 2777 known species harbor 66 zoonotic agents (Han et al., 2015). Considering this scenario, and the recent detection of Borrelia spp. in rodent-associated ticks in Chile, we aimed to assess the presence of Borrelia DNA in 12 species of small mammals (ten rodents and two marsupials) from this country. We detected DNA of Borrelia spp. belonging to the LB and RF groups in two cricetid rodents, namely P. xanthopygus and O. Iongicaudatus, respectively. While cricetid rodents (i. e. Peromyscus leucopus) have been previously reported as competent reservoirs for Borrelia burgdorferi sensu stricto (s.s.) in North America (Levine et al., 1985; Hofmeister et al., 1999; Bunikis et al., 2004), high prevalence for Borrelia burgdorferi s.l. have been reported in synanthropic murid rodents (Mus musculus and Rattus rattus) too (Solís-Hernández et al., 2016). In our study, synanthropic M. musculus were negative to Borrelia detection, a fact that could be attributed to the small sample of this species that was analyzed.

Apart from rodents, we assessed blood from marsupials, but with negative results. Nevertheless, Borrelia-like spirochetes have already been isolated from opossums (Marsupialia) in the United States (Hanson, 1970), so the role of Chilean marsupials as hosts for Borrelia spp. should not be discarded. Studies focusing on small mammals and enzootic cycles of borrelial spirochetes have been performed only for Northern (Levine et al., 1985; Hofmeister et al., 1999; Bunikis et al., 2004) and Central American species (Solís-Hernández et al., 2016). Whether rodents may act as reservoirs for Borrelia in South America remained unknown until the current study.

Parola et al. (2011) detected a RF Borrelia sp. (Borrelia sp. 95325, HM583797) in an undetermined Ornithodoros sp. collected in Bolivia. Remarkably, the flaB gene sequence retrieved by Parola et al. (2011) formed an independent clade with the sequences obtained in our study (Borrelia sp. A10 and Borrelia sp. A44), suggesting a close phylogenetic relationship. The phylogenetic resolution of the flaB gene has been useful to define lineages in the genus Borrelia (Fukunaga et al., 1996). In agreement with this fact, our BI and ML analyses indicated with high support that the detected genotypes constitute putatively new species (Figure 2). According to these results, the BI and ML phylogenies for IGS also point that the sequences of Borrelia sp. A10 and Borrelia sp. A44 constitute novel taxa, related to RF borreliae (Figure 3). To date, only one rodent parasitized by an Ornithodoros sp. has been proposed as putative reservoir for a RF Borrelia sp. in Chile (Muñoz-Leal et al., 2019b). However, the sequences detected in this study differ from Borrelia genotypes previously detected in soft ticks from this country (Muñoz-Leal et al., 2019a).

Different genotypes of flaB gene belonging to the LB group have been reported in Chile, namely Borrelia sp. Navarino (MH178398), characterized from Ixodes auritulus collected in the bird a Troglodytes musculus, and 
several genotypes related to B. chilensis from ticks of the I. sigelos group (MH178397, MH187987, CP009910; Ivanova et al.2014; Muñoz-Leal et al., 2019a). Even though those studies have made valuable contributions to the understanding of the diversity of Borrelia in Chile, evidence of mammal hosts acting as reservoir for these agents was previously non-existent. In this study, sequences of Borrelia flaB gene retrieved from blood of 0 . longicaudatus (Borrelia sp. A53) branched as independent genotypes within the LB group of borreliae (Figure 2). Remarkably, Borrelia sp. A53 was also related to B. chilensis (CP009910), a genospecies previously reported in I. stilesi parasitizing the same rodent species in Southern Chile (Ivanova et al., 2014). Moreover, genotypes of Borrelia detected in larvae and nymphs of I. sigelos S.l. collected on P. darwini and Octodon degus (Muñoz-Leal et al., 2019a) clustered with Borrelia sp. A53 as well. This fact suggests that LB genotypes of Borrelia associated with rodents could constitute a monophyletic group related to $B$. chilensis. A similar hypothesis pointing a natural group of borreliae infecting rodents has been proposed through phylogenetic analyses using Borrelia genotypes detected in rodent-associated ticks in Southern Argentina (Sebastian et al., 2016).

To our knowledge, this is the first report of infection by Borrelia spp. in small mammals from Chile and South America, and the first isolation of DNA from these spirochetes in $P$. xanthopygus and $O$. longicaudatus. Our results suggest that these rodents may act as potential reservoirs for novel Borrelia genotypes in natural ecosystems of northern Chile. However, future studies are needed to further determine the competence of these rodents in maintaining Borrelia infections, and to investigate if other species of small mammals participate in the enzootic cycles of these spirochetes as well.

\section{Acknowledgments}

We thank Ignacio Troncoso, Constanza Aguilera, Andrea Cotes, Diana Echeverry and Juan Uribe for their collaboration during this research project. We also appreciate the support provided by the Livestock and Servicio Agrícola y Ganadero (SAG), Corporación Nacional Forestal (CONAF) and Universidad de Concepción. This study has been funded by the National Fund for Scientific and Technological Development (FONDECYT) N $N^{\circ} 1170972$ and by the CONICYT PFCHA/DOCTORADO BECAS CHILE/2019 - 21190078. Funders had no role in the study design, data collection, analysis, preparation of the manuscript, and decision to publish it. Authors would like to thank Diane Haughney for the correction of the English text.

\section{References}

Birkenheuer AJ, Levy MG, Breitschwerdt EB. Development and evaluation of a seminested PCR for detection and differentiation of Babesia gibsoni (Asian genotype) and B. canis DNA in canine blood samples. J Clin Microbiol 2003; 41(9): 4172-4177. http:// dx.doi.org/10.1128/JCM.41.9.4172-4177.2003. PMid:12958243.

Bunikis J, Garpmo UF, Tsao J, Berglund J, Fish D, Barbour AG. Sequence typing reveals extensive strain diversity of the Lyme borreliosis agents Borrelia burgdorferi in North America and Borrelia afzelii in Europe. Microbiology 2004; 150(6): 1741-1755. http://dx.doi.org/10.1099/mic.0.26944-0. PMid:15184561.

Cutler S, Ruzic-Sabljic E, Potkonjak A. Emerging borreliae - expanding beyond Lyme borreliosis. Mol Cell Probes 2017; 31: $22-27$. http://dx.doi.org/10.1016/j.mcp.2016.08.003. PMid:27523487.

Cutler S. Relapsing fever Borreliae: a global review. Clin Lab Med 2015; 35(4): 847-865. http://dx.doi.org/10.1016/j.cll.2015.07.001. PMid:26593261.

Donahue JG, Piesman J, Spielman A. Reservoir competence of white-footed mice for Lyme disease spirochetes. Am J Trop Med Hyg 1987; 36(1): 92-96. http://dx.doi.org/10.4269/ajtmh.1987.36.92. PMid:3812887.

Felsenstein J. Inferring phylogenies. Massachusetts: Sinauer Asociates; 2004.

Filatov DA. Processing and population genetic analysis of multigenic datasets with ProSeq3 software. Bioinformatics 2009; 25(23): 3189-3190. http://dx.doi.org/10.1093/bioinformatics/btp572. PMid:19797407.

Fukunaga M, Okada K, Nakao M, Konishi T, Sato Y. Phylogenetic analysis of Borrelia species based on flagellin gene sequences and its application for molecular typing of Lyme disease borreliae. Int J Syst Bacteriol 1996; 46(4): 898-905. http://dx.doi. org/10.1099/00207713-46-4-898. PMid:8863416.

Guttman DS, Wang PW, Wang IN, Bosler EM, Luft BJ, Dykhuizen DE. Multiple infections of Ixodes scapularis ticks by Borrelia burgdorferi as revealed by single-strand conformation polymorphism analysis. J Clin Microbiol 1996; 34(3): 652-656. http://dx.doi. org/10.1128/JCM.34.3.652-656.1996. PMid:8904432. 
Han BA, Schmidt JP, Bowden SE, Drake JM. Rodent reservoirs of future zoonotic diseases. Proc Natl Acad Sci USA 2015; 112(22): 7039-7044. http://dx.doi.org/10.1073/pnas.1501598112. PMid:26038558.

Hanson AW. Isolation of spirochaetes from primates and other mammalian species. Sex Transm Infect 1970; 46(4): 303-306. http://dx.doi.org/10.1136/sti.46.4.303. PMid:4990374.

Hazler KR, Ostfeld RS. Larval density and feeding success of Ixodes scapularis on two species of Peromyscus. J Parasitol 1995; 81(6): 870-875. http://dx.doi.org/10.2307/3284032. PMid:8544056.

Herbreteau V, Jittapalapong S, Rerkamnuaychoke W, Chaval Y, Cosson J-F, Morand S. Protocols for field and laboratory rodent studies. Bangkok: Kasetsart University Press; 2011.

Hofmeister EK, Ellis BA, Childs JE, Glass GE. Longitudinal study of infection with Borrelia burgdorferi in a population of Peromyscus leucopus at a Lyme disease-enzootic site in Maryland. Am J Trop Med Hyg 1999; 60(4): 598-609. http://dx.doi.org/10.4269/ ajtmh.1999.60.598. PMid:10348235.

Huelsenbeck JP, Ronquist F, Nielsen R, Bollback JP. Bayesian inference of phylogeny and its impact on evolutionary biology. Sciences (New York) 2001; 294(5550): 2310-2314. http://dx.doi.org/10.1126/science.1065889. PMid:11743192.

Huelsenbeck JP, Ronquist F. MRBAYES: bayesian inference of phylogenetic trees. Bioinformatics 2001; 17(8): 754-755. http:// dx.doi.org/10.1093/bioinformatics/17.8.754. PMid:11524383.

Iriarte A. Mamíferos de Chile. Santiago de Chile: Lynx Edicions Press; 2008.

Ivanova LB, Tomova A, González-Acuña D, Murúa R, Moreno C, Hernández C, et al. Borrelia chilensis, a new member of the Borrelia burgdorferi sensu lato complex that extends the range of this genospecies in the Southern Hemisphere. Environ Microbiol 2014; 16(4): 1069-1080. http://dx.doi.org/10.1111/1462-2920.12310. PMid:24148079.

Kalyaanamoorthy S, Minh BQ, Wong TKF, von Haeseler A, Jermiin LS. ModelFinder: fast model selection for accurate phylogenetic estimates. Nat Methods 2017; 14(6): 587-589. http://dx.doi.org/10.1038/nmeth.4285. PMid:28481363.

Karesh WB, Dobson A, Lloyd-Smith JO, Lubroth J, Dixon MA, Bennett M, et al. Ecology of zoonoses: natural and unnatural histories. Lancet 2012; 380(9857): 1936-1945. http://dx.doi.org/10.1016/S0140-6736(12)61678-X. PMid:23200502.

Khare P, Raj V, Chandra S, Agarwal S. Quantitative and qualitative assessment of DNA extracted from saliva for its use in forensic identification. J Forensic Dent Sci 2014; 6(2): 81-85. http://dx.doi.org/10.4103/0975-1475.132529. PMid:25125913.

Kumar S, Stecher G, Tamura K. MEGA7: molecular evolutionary genetics analysis version 7.0 for bigger datasets. Mol Biol Evol 2016; 33(7): 1870-1874. http://dx.doi.org/10.1093/molbev/msw054. PMid:27004904.

Kurtenbach K, Kampen H, Dizij A, Arndt S, Seitz H, Schaible UE, et al. Infestation of Rodents with Larval Ixodes ricinus (Acari; Ixodidae) Is an Important Factor in the Transmission Cycle of Borrelia burgdorferi s.I. in German Woodlands. J Med Entomol 1995; 32(6): 807-817. http://dx.doi.org/10.1093/jmedent/32.6.807. PMid:8551503.

Levine JF, Wilson ML, Spielman A. Mice as reservoirs of the Lyme disease spirochete. Am J Trop Med Hyg 1985; 34(2): 355-360. http://dx.doi.org/10.4269/ajtmh.1985.34.355. PMid:3985277.

Llanos-Soto S, González-Acuña D. Conocimiento acerca de los patógenos virales y bacterianos presentes en mamíferos silvestres en Chile: una revisión sistemática. Rev Chilena Infecto/ 2019; 36(1): 43-67. http://dx.doi.org/10.4067/S0716-10182019000100043. PMid:31095204.

Ministerio del Medio Ambiente - MMA. Biodiversidad de Chile: patrimonios y desafíos [online]. 3rd ed. Santiago de Chile: MMA; 2018 [cited 2019 Jun 25]. Available from: https://mma.gob.cl/wp-content/uploads/2019/04/Tomo-I-libro-Biodiversidad-ChileMMA-web.pdf

Minh BQ, Nguyen MAT, von Haeseler A. Ultrafast approximation for phylogenetic bootstrap. Mol Biol Evol 2013; 30(5): $1188-1195$. http://dx.doi.org/10.1093/molbev/mst024. PMid:23418397.

Müller A, Monti G, Otth C, Sepúlveda P, Bittencourt P, Nachum-Biala Y, et al. “Candidatus Neoehrlichia chilensis" sp. nov.: molecular detection and characterization of a novel Anaplasmataceae in wild rodents from Valdivia, southern Chile. Transbound Emerg Dis 2018; 65(2): 357-362. http://dx.doi.org/10.1111/tbed.12815. PMid:29363276.

Muñoz-Leal S, Lopes MG, Marcili A, Martins T, González-Acuña D, Labruna M. Anaplasmataceae, Borrelia and Hepatozoon agents in ticks (Acari: Argasidae, Ixodidae) from Chile. Acta Trop 2019a; 192: 91-103. http://dx.doi.org/10.1016/j.actatropica.2019.02.002. PMid:30735640.

Muñoz-Leal S, Marcili A, Fuentes-Castillo D, Ayala M, Labruna MB. A relapsing fever Borrelia and spotted fever Rickettsia in ticks from an Andean valley, central Chile. Exp Appl Acarol 2019b; 78(3): 403-420. http://dx.doi.org/10.1007/s10493-019-00389-x. PMid:31165944.

Nguyen L-T, Schmidt HA, von Haeseler A, Minh BQ. IQ-TREE: A fast and effective stochastic algorithm for estimating maximumlikelihood phylogenies. Mol Biol Evol 2015; 32(1): 268-274. http://dx.doi.org/10.1093/molbev/msu300. PMid:25371430. 
Parola P, Ryelandt J, Mangold AJ, Mediannikov O, Guglielmone A, Raoult D. Relapsing fever Borrelia in Ornithodoros ticks from Bolivia. Ann Trop Med Parasitol 2011; 105(5): 407-411. http://dx.doi.org/10.1179/1364859411Y.0000000021. PMid:21929883.

Rambaut A, Drummond AJ, Xie D, Baele G, Suchard M. Posterior summarization in bayesian phylogenetics using Tracer 1.7. Syst Biol 2018; 67(5): 901-904. http://dx.doi.org/10.1093/sysbio/syy032. PMid:29718447.

Rauter C, Hartung T. Prevalence of Borrelia burgdorferi Sensu Lato Genospecies in Ixodes ricinus Ticks in Europe: a Metaanalysis. Appl Environ Microbiol 2005; 71(11): 7203-7216. http://dx.doi.org/10.1128/AEM.71.11.7203-7216.2005. PMid:16269760.

Ronquist F, Teslenko M, Van Der Mark P, Ayres DL, Darling A, Höhna S, et al. MrBayes 3.2: efficient bayesian phylogenetic inference and model choice across a large model space. Syst Bio/ 2012; 61(3): 539-542. http://dx.doi.org/10.1093/sysbio/sys029. PMid:22357727.

Salinas P, Moraga R, Santander E, Sielfeld W. Presencia de cepas diarreogénicas de Escherichia coli y estudio de genes de virulencia en aislados desde fecas de dos poblaciones de lobo marino común, Otaria flavescens en el norte de Chile. Rev Biol Mar Oceanogr 2010; 45(1): 153-158. http://dx.doi.org/10.4067/S0718-19572010000100016.

Schwarz G. Estimating the dimension of a model. Ann Stat 1978; 6(2): 461-464. http://dx.doi.org/10.1214/aos/1176344136.

Sebastian PS, Bottero MNS, Carvalho L, Mackenstedt U, Lareschi M, Venzal J, et al. Borrelia burgdorferi sensu lato in Ixodes cf. neuquenensis and Ixodes sigelos ticks from the Patagonian region of Argentina. Acta Trop 2016; 162: 218-221. http://dx.doi. org/10.1016/j.actatropica.2016.06.030. PMid:27372197.

Solís-Hernández A, Rodríguez-Vivas RI, Esteve-Gassent MD, Villegas-Pérez SL. Prevalencia de Borrelia burgdorferi sensu lato en roedores sinantrópicos de dos comunidades rurales de Yucatán, México. Biomedica 2016; 36(Supl. 1): 109-117. http://dx.doi. org/10.7705/biomedica.v36i3.3139. PMid:27622631.

Stromdahl EY, Williamson PC, Kollars TM, Evans SR, Barry RK, Vince MA, et al. Evidence of Borrelia lonestari DNA in Amblyomma americanum (Acari: Ixodidae) removed from humans. J Clin Microbiol 2003; 41(12): 5557-5562. https://doi.org/10.1128\%2FJ CM.41.12.5557-5562.2003

Sturm N, Abalos P, Fernández A, Rodríguez G, Oviedo P, Arroyo V, et al. Salmonella enterica in Pinnipeds, Chile. Emerg Infect Dis 2011; 17(12): 2377-2378. http://dx.doi.org/10.3201/eid1712.111103. PMid:22172111.

Talagrand-Reboul E, Boyer PH, Bergström S, Vial L, Boulanger N. Relapsing fevers: neglected tick-borne diseases. Front Cell Infect Microbio/ 2018; 8: 98. http://dx.doi.org/10.3389/fcimb.2018.00098. PMid:29670860.

Thompson JD, Higgins DG, Gibson TJ. CLUSTAL W: improving the sensitivity of progressive multiple sequence alignment through sequence weighting, position-specific gap penalties and weight matrix choice. Nucleic Acids Res 1994; 22(22): 4673-4680. http:// dx.doi.org/10.1093/nar/22.22.4673. PMid:7984417.

Toro M, Retamal P, Allard M, Brown EW, Evans P, Gonzalez-Escalona N. Draft genome sequences of 33 Salmonella enterica clinical and wildlife isolates from Chile. Genome Announc 2015; 3(2): e00054-e15. http://dx.doi.org/10.1128/genomeA.00054-15. PMid:25792040. 